\title{
MEETING THE NORTHWEST'S ENERGY NEEDS THROUGH COMPETITIVE BIDDING
}

\author{
Prepared by: \\ Gilbert A. McCoy \\ and \\ R. Gordon Bloornquist \\ of the \\ Washington State Energy Office \\ 809 Legion Way SE, FA-11 \\ Olympia, Washington 98504 \\ Richard H. Watson, Director
}

Funded by:

Bonneville Power Administration

United States Department of Energy

July 1990 


\section{ACKNOWLEDGMENTS}

The authors wih to thank the U.S. Department of Energy and the Bonneville Power Administration for their financial contributions to this effort. Thanks are also due to the many public service commission, utility, and energy service company staff who shared their time and experience.

\section{DISCLAIMER}

This report was prepared by the Washington State Energy Office as an account of work sponsored by the United States Government. Neither the United states nor the Bonneville Power Administration, the State of Washington, the Washington State Energy Office, nor any of their employees, nor any of their contractors, subcontractors, or their employees, makes any warranty, expresssed or implied, or assumes any legal responsibility for the accuracy, completeness, or usefulness of any information, apparatus, product, or process disclosed within the report.

\section{DISCLAIMER}

\footnotetext{
This report was prepared as an account of work sponsored by an agency of the United States Government. Neither the United States Government nor any agency thereof, nor any of their employees, makes any warranty, express or implied, or assumes any legal liability or responsihility for the accuracy, completeness, or usefulness of any information, apparatus, product, or process disclosed, or represents that its use would not infringe privaltely owned rights. Reference herein to any specific commercial product, process, or service by trade name, trademark, mantifacturer, or otherwise does not necessarily constitute or imply its endorsemen, recommendation, or favoring by the United States Covernment on any agency thereol. The views and opinions of authors expressed herein do not necessarily state or reflect those of the United States covernment or any agency thereof
} 


\section{MEETING THE NORTHWEST'S ENERGY NEEDS THROUGH COMPETITIVE BIDDING}

\section{Introduction}

Utilities have traditionally met load growth requirements through building generating projects (self-build), purchasing power from other utilities, or from running conservation programs. During the 1980s, alternative capacity expansion approaches were developed. Resources are now also obtained through PURPA-based or competitive bidding acquisition programs.

Self-build programs typically involve large-scale hydropower; coal-, natural gas-, and oil-fired projects; and nuclear thermal electric generating projects. Characteristics of these projects, in addition to size, include long lead times, capital intensiveness, substantial environmental impacts, and a significant risk of cost overruns. The risk element became immediately apparent to those investor-owned utilities that, because of decreased load growth, had thermal project investments disallowed in rate cases or were forced to terminate projects. Phrases such as "prudent investment," "used and useful," and "least-cost planning" became familiar to the utility industry. Many utilities, once burned, subsequently adopted a policy of never again constructing a base-loaded generating plant.

Meanwhile, the federally-mandated PURPA-based resource acquisition process took hold. While PURPA was originally conceived as a means of reducing oil consumption and our reliance on foreign imports, it quickly became apparent that some regulators viewed PURPA as the preferred way for utilities to acquire resources to satisfy load obligations. Regulators were weary of dealing with utility cost overruns and viewed contracts based on a utility's projected avoided costs as a way of minimizing risks and stabilizing rates. Utilities, developers, and financiers alike favored the assurances yielded by Public Service Commission (PSC) review and approval of their power purchase contracts.

PURPA, however, was not without its problems. In California, for example, utilities became oversubscribed with resources due to the PSC approval of open-ended standard offers. In retrospect, the contracts signed based on the avoided cost projections at that time are overly generous and not in the ratepayer's or the utility's interest. In an effort to stimulate renewable resource development and decentralized generation, New York's legislature established a 6 cents/kWh avoided cost minimum or purchase price floor rate. A development gold rush ensued when declining natural gas prices enabled cogeneration and combined cycle projects to produce immediate profits. A single upstate New York utility, Niagara Mohawk, was forced to sign PURPA contracts with 171 projects representing 2,843 MW of generating capacity.

Developer dissatisfaction with PURPA grew as utilities that were reluctant to obtain excessive quantities of new resources delayed negotiating and signing contracts by establishing elaborate interconnection requirements, or by presenting transmission, wheeling, insurance, or frontloaded security requirement obstacles. Environmentalists were outraged as hydropower applications were filed on creeks with high fisheries, wildlife, and recreational values. Utilities, forced to acquire on a first-come/first-served basis, had to rely on uncertain or "phantom resources" to meet future loads. Uncertainties abounded as no penalties were levied against developers to discourage them from walking away from a project or a contract.

In some cases, reliance on phantom resources caused utilities to defer conservation programs and delay investments on lower priced energy efficiency measures. Exposure to a sudden loss of anticipated resources could also harm ratepayers by forcing a utility to invest in short-lead-time projects with high running costs. Finally, the requirement that a utility must acquire any resource offered at a rate based upon full avoided costs, made least-cost energy planning difficult, if not impossible. 
Competitive bidding evolved as a way to bring order to a disorderly market. In some states, bidding was proposed by the utility regulators; in others, it was developed by utility staff; and in yet others, it was supported by the resource development community. Over time, bidding schemes have included energy conservation or demand reduction resources and incorporated environmental policies, values, and cost-effectiveness goals. Programs have been designed to capture economic efficiencies, identify reliable project developers, reduce ratepayer risks, secure fuel supply and resource diversity objectives, and obtain resources that are of the highest value to the purchaser while conforming to regional policies and least-cost expansion planning principles.

Competitive bidding is not, however, without its drawbacks. Some utilities have accepted resources that were not sited, unable to obtain environmental approvals, or unable to secure a reliable long-term supply of fuel. Submitting a good response to a competitive bidding solicitation and negotiating attractive power purchase contracts are meaningless actions if the counted upon projects fail to materialize. These early problems have hopefully been resolved through modifications to project scoring, ranking, and evaluation systems and by requiring prospective bidders to post bidding fees and security deposits.

Competitive bidding should never perform worse than a PURPA-based resource acquisition system. Consider this scenario. If all projects were bid at full avoided cost and were awarded an identical number of scoring points, selection would be based wholly upon such parameters as project status and economic viability, experience of the project sponsor, site control, posting of security, and establishment of a liquidated damages fund; stability and reliability of fuel supply; project location, type, and size; environmental impacts and benefits; and conformance of the project's electricity production characteristics with the purchaser's energy requirements. These essential criteria are not applied to a PURPA-based acquisition.

Competitive bidding enables the resource acquirer to minimize uncertainty and risk by identifying and selecting projects:

- With a high likelihood of being developed

- That are consistent with regional energy and environmental plans and policies

- That best meet the utility's needs

Competitive acquisition also enables utilities to identify their actual avoided costs and pursue least-cost planning objectives by offering integrated or all-sourc $\bullet$ bidding solicitations.

Competitive bidding shows promise as a straightforward and orderly way of acquiring resources to meet forecasted growth in electrical loads. A competitive bidding program for the northwest. should be designed to ensure that both an environmentally acceptable and least-cost mix of conservation and supply side resources is available to meet future regional electricity needs.

Competitive resource acquisition can simultaneously be used to reduce the purchasing utility's risk and investment requirements, minimize ratepayer costs, achieve least-cost planning objectives, foster economic development, and minimize external environmental or societal costs.

A utility can use bidding to meet all or a portion of a supply block. Demand-side bidding can be used to supplement or supplant utility-sponsored conservation programs. A competitive solicitation can be open to "all sources" or can be restricted only to generating or demand-side resources. A Request For Proposals can be "targeted" to specific measures, potential lost-opportunities, or technologies. Bidders with renewable resources, innovative projects, or emerging technologies can be encouraged to or discouraged from participating. In sum, competitive acquisition offers tremendous flexibility and opportunity to the user. It is also a tool that must be well understood in order to be used to its greatest advantage. 
A multitude of judgment calls must be made during the design of a competitive bidding process. The success of the bidding program ultimately hinges upon how well these decisions are made. No single competitive bidding concept is "best," nor should all future energy needs be met through competitive bidding.

Currently, existing competitive acquisition programs have been custom designed to meet explicit or implicit sets of utility and public service commission goals and objectives. Program design and structural opportunities abound. Options exist within the general areas of bidding approaches; supply block determination and auction frequency; avoidod cost calculation; establishment of threshold conditions; project scoring, ranking, and evaluation criteria; methodology used to incorporate external environmental and societal costs; security requirements and risk minimization techniques; conservation energy savings evaluation methodology selection; and contracting issues.

Any competitive bidding program should be consistent, both internally and to conform with resource acquisition policies, goals, and objectives. Accordingly, this paper is divided into three sections. The first section establishes the goals and objectives of designing and conducting a northwest competitive resource acquisition program. The second section identifies the options, issues, and choices faced by those designing such a program. The third section contains state energy office staff recommendations regarding the design and operation of a comprehensive competitive acquisition program.

\section{Competitive Resource Acquisition Goals and Objectives}

A list of regional goals and objectives should be developed before attempting to structure a competitive bidding program. Possible goals and objectives include:

- Establishing an orderly pro ess for acquiring resources. A process that requires developers to bring their pr jects to the table at one time and enables purchasers to make choices based on fur i supply characteristics, performance, environmental consequences, economics, and risk. Bidding inherently offers more flexibility and less risk than the "must-acquire," first-come/first-served PURPA-based approach.

- Keeping the process timely and simple enough to encourage widespread participation by a diverse array of qualified resource providers. Economic benefits can only be obtained if a wide variety of resource choices are available.

- Establishing a "level playing field" that encourages true competition among resource types and between resource providers, without precluding the development of viable options.

- Implementing environmental policies through incorporation of appropriate weights in the project ranking and evaluation process.

- Providing the infornation necessary for a resource developer to optimize a project's configuration while readily ascertaining its competitiveness.

- Obtaining the type and quality of demand and supply options that are in the best longterm interests of the region's ratepayers.

- Gaining control over capacity and energy additions to meet customer and system needs while avoiding unnecessary rate increases. 
- Maintaining consistency and compatibility with regional energy planning efforts.

- Fostering a least-cost planning approach by capturing available economic efficiencies.

- Reducing financial risks associated with paying for energy at rates in excess of projected avoided costs.

- Minimizing the potential for litigation while encouraging a harmonious "partnership" between public and private sector developers and the power purchaser.

\section{Competitive Bidding Program Issues and Choices}

Competitive acquisition is an inherently simple concept. At the same time, a multitude of choices are available and many decisions must be made to structure a workable program that reflects the purchasers' goals and objectives. It is important that program design elements bc consistent both with each other and with the region's goals. Is is also critical that the bidding program be easily understood and its ground rules fairly administered. Many potential participants will undoubtedly offer comments designed to provide advantages to their programs and projects or that serve to hamstring and eliminate competitors. It is incumbent upon the Bonneville Power Administration (BPA) to make wise choices that reflect regional goals and objectives, foster competition, and ultimately bring the best available projects to the table. This section of the paper summarizes competitive acquisition program design considerations and choices.

\section{Program Design, Organization and Mechanics}

- Conduct "all source" bidding or limit competitiva acquisitions to supply side resources.

- Offer joint conservation solicitations or issue separate RFPs.

- Use the same scoring scheme for supply and demand-side management (DSM) resources or prepare separate and independent ranking criteria.

- Achieve programmatic savings in targeted sectors or depend on bidding for all resource acquisitions.

- Hold a mandatory or discretionary bidders conference with information available to all.

- Consider requiring bidders to file a Notice of Intent, prior to submittal.

- Consider awarding bonus points based on project location (for economic development or transmission enhancement).

- Consider first (discriminative) or second price auction concepts.

- Apply bidding territory restrictions or establish "open access."

- Consider franchising by/of utility service territories to eliminate overlapping proposals. 
- Consider benefits of a closed versus a "transparent" self-scoring approach.

- Develop a closed, negotiation intensive process or one open to the public with copies of submitted bids made available after the selection process is completed.

- Withhold or supply ready access to information.

- Open bidding to Qualifying Facility (QF) and Independent Power Projects (IPP) or restrict access to certain developer classes.

- Use bidding as a "screening tool" to establish an initial award group or immediately offer contracts to "winners."

- Allow or disallow energy savings from fuel switching.

- Develop a policy regarding treatment of public projects subsidized by tax-exempt financing.

- Prepare a policy to deal with cream-skimming and free-rider issues.

- Consider limits on the number of bids allowable by one developer for a single site.

- Promote administrative simplicity and flexibility.

- Consider providing a simple track for smaller projects, with acquisition at average or maximum bid prices.

- Consider offering technical assistance programs to aid small utilities with project contracting and interconnection issues.

- Assist utilities in establishing interconnection standards and requirements that are appropriate to the type and scale of the generating resource.

- Consider ways of eliminating gold plating. Fully define interconnection requirements by standardizing equipment and practice. Make such information readily available.

- Consider utilities as contract negotiators with BPA reimbursement for administrative and overhead costs.

- Develop an approach for the treatment of utility life-extension projects.

- Address wheeling issues. Consider assigning postage stamp rates.

- Consider awarding "bonus" points to DSM, QF, and efficiency improvement projects.

- Develop procedures for the treatment of disclosure requirements and proprietary information.

- Decide whether to conduct a PURPA acquisitions process outside of bidding. Decide how utility purchases will be handled.

- Decide whether to make contracts available for independent power producers and traditional suppliers outside of bidding (short term, long term). 
- Prepare guidelines for bid submission and acceptance with procedures for disposing of protests.

- Identify the bid conductor. Decide who issues RFPs, selects bid winners, enforces contracts and resolves conflicts.

- Conceive of a methodology to deal with lost opportunity resources.

- Develop a methodology for the treatment of innovative technologies.

- Address DSM market design, coverage, and conservation program overlap issues.

\section{Supply Biocks and Increments}

- Establish a minimum bidding frequency.

- Determine minimum supply block or increment sizes.

- Establish an appropriate bidding horizon.

- If bidding is used as a screening tool, consider an initial award group equal to a minimum of 150 percent of resources needed, or 250 percent times that of the largest project in the initial award group.

\section{Avoided Cost}

- Establish a procedure to identify future power plant requirements and avoided costs. (Base on an avoided plant, use differential revenue requirements method, or administratively determine.)

- Establish an avoided cost or scoring cap and present it in the solicitation.

- Consider allowing developers to exceed the cap if total awarded points beat the avoided plant score.

- Consider determining avoided costs for various supply groups and characteristics such as unscheduled energy only, capacity by season, and firm and non-firm energy.

- Provide flexibility with respect to contract length.

- Select a planning horizon length.

- Consider awarding front-loaded, fixed-price, fixed-plus- variable price, or fuel-priceindexed power purchase cuntracts.

- Allow or disallow fuel price indexing.

- Enable a developer to provide multiple offers (perhaps with the same net present value).

- For DSM resources, consider paying the full cost of installing measures up-front or the full cost less the first year savings. 


\section{Threshold Conditions}

- At a minimum, require the bidder to submit a proposal that is responsive to and fulfills the requirements of the purchaser's RFP.

- Require all applicants to be qualified and eligible to receive an award under applicable federal and state laws and regulations.

- Consider establishing project generating capacity or expected annual electrical output minimums.

- Establish requirements that bidders be in business for a minimum period of time or be able to demonstrate the successful completion of similar projects.

- Require that bidders be willing to provide a minimum contract deposit.

- Allow a bid to be considered only if the bidder's price offer' is at or below a ceiling price (or a ceiling score).

- Consider requiring the payment of a non-refundable entry fee.

- Consider requiring the project sponsor to provide acceptable documentation that it owns or has a lease for a suitable site or that it has a firm commitment from a site owner.

- Consider requiring evidence of zoning suitability.

- Consider requiring cogeneration project sponsors to provide a firm commitrnent on the part of the thermal host to negotiate a purchase agreement in good faith.

- Consider requiring project sponsors to provide satisfactory evidence of access to and availability of fuel at the site for the term of the project.

- Consider requiring a "project definition" statement. This would identify the project participants and the management team, indicate the technology to be used, summarize air pollution control and cooling and makeup water requirements, contain a conceptual design with heat balances, illustrate operating and maintenance plans, provide installed costs and debt coverage ratio projections, and estimate time variant capacity and energy deliveries.

- Consider requiring sponsors to provide a project-specific plan that identifies all required permits, licenses, and approvals.

- Consider requiring sponsors to identify a point of interconnection and wheelin: requirements.

- Consider requiring a financing plan and a preliminary milestone schedule.

- Consider establishing minimum and maximum contract term limits.

- Evidence of FERC certification of qualifying facilities may be required. 


\section{Project Scoring, Ranking, and Evaluation Criteria}

- Develop an evaluation scheme that is explicit and objective to allow for developer project optimization and self-scoring.

- Consider price only bidding or establish weights and award points for project technology and performance characteristics, developer experience, mitigation of environmental impacts, security deposits, project licensing, and developmental status.

- Establish a methodology for balancing price versus non-price factors.

- Consider establishing a bid price floor to be used with a linear or non-linear scoring scale.

- Consider allowing the lowest priced bid submitted to establish the floor price.

- Consider allowing bonus points for fixed-price contracts.

- Weigh use of "all-or-nothing" attribute scoring.

- Prepare a policy to allocate risks associated with unexpected fuel price increases.

- Design an acquisition system that procures a diverse mix of fuel types and generating resource technologies.

- Ensure equitable treatment of renewable resources.

- Consider contract terms (favor longer or shorter contracts).

- Decide whether negotiation within an initial award group should be allowed to improve scores.

- Require proposers to demonstrate project viability with points awarded for an approved site, engineering, financial plan, design, licensing plan, developer experience, and security deposit.

- Develop values for efficiency, dispatchability, economic dispatch, reliability, and spinning reserves.

- Consider awarding points for the presence of maintenance contracts.

- Allocate extra points or credits to projects with improved thermal or fuel efficiency.

- Provide thermal sales bonus points and/or a FERC certification bonus.

- Consider the development of software that translates purchase price streams and nonprice factors into an aggregate project score.

\section{Environmental Considerations}

- At a minimum, require the developer to comply with all applicable environmental permits and licensing requirements. 
- Take into account such factors as airborne emissions, water consumption, liquid and solid waste generation, transmission line requirements, and land use impacts.

- Include environmental externalities in the bid ranking scheme. Compare the cost of mitigating externalities to electricity production costs and the value (loss) associated with the external environmental impacts.

\section{Security Requirements and nisk Minimization:}

- Establish performance guarantees with penalties for non-performance.

- Require graduated security deposits that are coupled with development milestones.

- Establish a liquidated damages fund.

- Require a bidders fee.

- Consider refundable deposits.

- Provide benefits for an early on-line date coupled with penalties or increased security for delayed start up (or vise-versa).

- Link security provisions to the degree of proposed price levelization.

- Establish capacity or capacity factor penalties.

- Allow developers to post increased security deposits to extend their contractual service date.

\section{Demand-Side Management Issues}

- Structure payments to provide a "level playing field."

- Consider the use of rate or "no-loser" tests.

- Consider providing up-front payments or rebates for all or a percentage of incurred installation costs.

- Allow and facilitate end-user participation while simultaneously providing for Energy Service Company (ESCO) or third party financing mechanisms.

- Define an appropriate evaluation methodology for different types of conservation resources. Lighting retrofits may require only engineering estimates or before and after amperage draws. Refrigeration improvements or high-efficiency motor change outs might entail submetered before and after monitoring for a limited period of time (i.e., one week). Energy Management System (EMS) or building envelope measures could require a comparison of annual weather corrected (for both heating and cooling degree days) baseline, and after installation measurernents.

- Prepare tables showing energy savings, demand reductions, and maximum incentives for a range of lighting retrofits, energy efficient HVAC, chiller and motor replacements, refrigeration improvement technologies, and energy management systems. Savings estimates could then quickly be made by multiplying the number of measures installed in each technological category times the savings per measure. 


\section{Contract Formation}

- Est iblish a standard format or generic contract to minimizo negotiations.

- Ensure the contract is financable.

- Establish time lines and deadlines for negotiating and signing contracts.

- Offer contracts with variable lengths.

- Consider supplying a "Notice of Intent to Bid" form.

- Develop a process to clarify and verify project sponsor representations.

\section{Recommendations Regarding Competitive Resource Acquisition}

It would not be productive to write a paper describing the pros and cons of each of the issues that could be raised when structuring a competitive bidding approach. That task has already been undertaken and was done in detail (see New York Public Service Commission, Description of Bidding Elements and the Options on Those Elements, and Staff Position Paper on the Advantages and Disadvantages of Bidding and Avoided Cost Pricing (ACP) Alternatives Relative to the Current System for the Provision of Electricity Supplies.)

Instead, Washington State Energy Office (WSEO) staff will make a series of recommendations regarding the attributes that should be present in a regional acquisition program for the Northwest. We have met with regulators and utility personnel, while exarnining the acquisition programs developed in New York by Niagara Mohawk Power Corporation, Long Island Lighting Company, and Orange and Rockland Utilities; in New Jersey by Jersey Central Power and Light and Public Service Electric and Gas; in Massachusetts by Boston Edison and New England Power Company; and in Virginia by Virginia Electric Power Company. There is no "best" RFP or bidding program design. In fact, there is tremendous diversity and controversy over the effectiveness of the various programs currently being offered. While utilities in the Northeast are generally acquiring capacity rather than energy, certain elements of existing programs appear particularly well developed and should be applicable to the northwest.

Design of a competitive bidding approach is a balancing act. Key Issues include:

- Determining treatment of supply versus conservation resources

- Maintaining flexibility or using bid evaluation results to select winning projects

- Eliminating utility and ratepayer risks while not imposing undue security and financial burdens on resource providers

- Using threshold conditions to restrict participation or eliminating entry barriers to facilitate free-market interactions

- Considering price versus non-price factors

- Considering an open self-scoring versus a closed process 
In this paper, state energy office staff recommend a competitive bidding resource acquisition process based on their preferences. These recommendations do not represent an official "state(s)" position. There is no state position. Rather, these recommendations are an attempt by knowledgeable individuals to integrate attractive elements of programs develc,ped elsewhere into a comprehensive approach that is consistent with northwest regional resource acquisition goals and objectives.

\section{Competitive Bidding Program Design, Organization and Mechanics}

The Bonneville Power Administration shouid design an all-source competitive bidding process that is fully transparent. Complete and adequate information should be made available such that participants can fully optimize and self-score their projects. The process should be "user friendly" and simple enough to attract a wide range of participant and technology types. IPPs, ESCO, or end-user developed DSM projects, utility transactions, and transfers should be allowed. To the extent possible, a "level playing field" should be established such that supply and demand-side projects are directly comparable.

A discriminative auction is preferred with bidding used as a screening tool to identify an initial award grou,? Niagara Mohawk wisely selects an initial award group equal to the larger of 150 percent of its resource need or 250 percent times that of the largest project in the initial award group. Projects within this award group are prioritized and contracts awarded based upon fuel supply availability and technology diversity; the project's location and performance characteristics; compatibility with regional planning efforts; and the region's electrical needs. Additional resources should be "in the queue" should negotiations fail on a particular project. Energy savings from fuel switching should be allowable.

It should be recognized that competitive bidding is but one resource acquisition tool. BPA should be free to offer targeted conservation programs, foster technological innovations, conduct pilot projects, obtain lost opportunity resources, and negotiate acquisitions outside of the competitive bidding arena. Environmentally acceptable projects providing less than $5 \mathrm{MWa}$ should be eligible for acquisition at the highest price offered during the previous bidding cycle. We must also realize that competitive bidding techniques and approaches are rapidly developing and evolving. Our program will not be "perfect." We must retain the ability to modify and refine our approach so that cost-effective resources can readily be obtained to meet future needs.

\section{Supply Blocks and Increments}

A supply block is the total amount of resource that is sought while an increment is the quantity of energy and/or capacity desired in a given year. Offering small supply blocks hinders the capture of economies of scale that are inherent in larger projects. Resource providers need to know the ground rules--that BPA will be issuing a competitive bidding solicitation on an annual or biannual basis. Supply blocks of less than $100 \mathrm{MWa}$ are not encouraged while a bidding horizon of 4 to 6 years is necessary for capital and license intensive renewable resources projects to effectively compt te.

\section{Avoided Cost Considerations}

Bonneville's avoided cost, or regional cost of designing, building, owning, and operating a designated "avoided plant" should be clearly stated within the competitive bidding request for proposals. An approach similar to that used by Orange and Rockland is highly encouraged. Orange and Rockland's avoided plant is scored based on price and non-price factors, and its scoring sheet is contained within the bidding solicitation. 
The avoided cost can be broken out by quality of energy provided, considering annual capacity factors, firm versus non-firm characteristics, and seasonality aspects. Flexibility should be provided to resource developers regarding front-loaded, indexed, or fixed plus variable price power purchase contracts. Projects should be considered as long as the net present value, using BPA's discount rate, for a string of purchase prices is equal to or less than the costs of constructing and operating the avoided plant.

Developers should be allowed, and even encouraged, to make multiple price offers for a single project. BPA would then be free to select the option that best meets its requirements. Respondents should be enabled to offer energy under a minimum contract length (10 years) up to the lesser of the expected technology life or 35 years.

\section{Threshold Conditions}

Threshold conditions can be used to limit market entry to only the largest, most experienced, and financially strong developers. Some utilities, Jersey Central Power \& Light, for instance, require bidders to post a $\$ 5,000$ non-refundable deposit to even be eligible to bid.

Establishing such entry barriers hinders the workings of the free market. State energy office staff favor encouraging widespread participation by minimizing threshold requirements. Sound projects and experienced developers should be selected through the scoring, ranking, and evaluation process and through requirements for the posting of security deposits when a power purchase contract is awarded. Least-cost acquisition can only be achieved when a complete array of resource choices is "on the table."

\section{Project Scoring, Ranking and Evaluation Criteria:}

Competitive bidding programs typically weigh economic or price factors; economic confidence or risk factors; project status and development confidence (success and viability) factors; operating characteristics; performance and longevity factors; system optimization factors; and non-economic factors, including environmental considerations.

The price and economic confidence factors are typically weighed to yield 50 to 70 percent of the total available score. California is the only state to consider price only bidding.

By dufinition, projects offering their output at full avoided cost receive no price points. Some utilities (Niagara Mohawk) have established a linear scale where a developer would have to provide energy fo: free to receive the total available price points. One must distinguish between the apparent and the effective price signal. The result of Niagara Mohawk's pricing formula is that a project offering output at 90 percent of avoided cost would receive only 10 percent of the available price points. The price emphasis is effectively suppressed, with few additional points awarded for a project willing to sell at 85 rather than 90 percent of avoided cost. The signal to the developer is to offer energy at full avoided cost while attempting to pick up points elsewhere.

Other utilities (Long Island Lighting) use a linear scale with full price points awarded to the least expensive resource offered. In their "Stipulation of Settlement," the New Jersey Board of Public Utilities sets a bid floor at 25 percent of the avoided cost ceiling. Price scoring is distributed on a linear scale with the floor receiving 100 percent and the ceiling none of the allowable points for price. Still other utilities (Orange \& Rockland) award price points from a non-linear table. Orange \& Rockland also awards negative price points for projects that exceed their projected avoided costs. Projects with higher avoided costs could be acquired if their environmental, performance, and risk benefits offset their avoided cost penalty. 
We recommended that BPA develop a price scoring formula that encourages the acquisition of least-cost resources. A linear scale could be used with full price points awarded to the lowestcost resource offered or for all projects offered below a pre-established level (i.e., 65 or 70 percent of full avoided costs). Alternatively, BPA could develop a graduated or non-linear pricing formula that gives a "correct" price signal to resource providers. One approach might be for BPA to select a price weighting factor and price/point line slope such as a 1 percent reduction in the bid avoided cost yields one additional price point. (A 2:1 slope is appropriate for a 50 percent price weighting factor.)

It should be recognized that project developers will compute the value of a "price point." This value is typically dependent upon project characteristics such as size and capacity factor; and financial parameters such as contract life, discount rate, and bid price offer. The developer will seek the least-cost approach to maximizing the project's score. If price points are too highly valued, the signal to the developer is to procure additional scoring points through investing in lower-cost non-price factors.

It is , thus, important that the points assigned to non-price factors be weighted in accordance with the actual value to the purchaser of those factors. For instance, assume that one price point is "valued" at $\$ 250,000$. If two points are awarded, given that the developer provides project design drawings, the signal to the developer is to optimize the project's score by being willing to invest up to $\$ 500,000$ for the preparation of design drawings. If design drawings can be procured for as little as $\$ 25,000$, all developers should supply them. In this case, the criteria would do little to differentiate between winning and losing bidders.

Alternatively, the provision of design drawings could be treated as a threshold requirement. With the value of points coupled to the cost (to BPA and to the developer) of securing additional points, the developer should invest up to his/her project's incremental point cost to provide additional design drawings, security, maintenance plans, and environmental controls. Willingness to pay for acquiring non-price points is thus properly equated to the cost to the developer of securing price-related points.

An additional weight of 2 to 10 percent of the total available score could be awarded for price risk, front-end loading, fuel price indexing, type and amount of security offered by the project sponsor $)$ mitigate the effects of front-loading, and project economic confidence. Boston Edison awards 25 percent of its total points to "economic confidence factors." Almost half of this total is awarded based on the project's "break even period," e.g., the time over which the net present value of total payments remains less than or equal to the total avoided costs.

Project performance need not be emphasized in the scoring and ranking tables. The scoring tables would be used as a screening tool with the value of projects in the initial award group determined with the Decision Analysis models. Factors such as resource diversity, intermittency versus baseload output, dispatchability, and seasonality would be considered and negotiated during the analysis period. BPA should supply information in the RFP so that project sponsors can optimize the performance and capabilities of their projects.

Approximately 15 to 25 percent of a project's score should be based on project status and viability factors (also called project development confidence factors). Factors for which points could be awarded include:

- Project technology/technical and environmental feasibility

- Project management team/sponsor's experience in developing similar projects

- Engineering design

- Project permitting plan, schedule, and milestones

- Project financing plan and schedule 
- Operation and maintenance plain

- Form of liquidated damages fund

- Sponsor's willingness to post an increased security deposit

- Debt coverage/Return on equity

- Marketing plan (for conservation resources)

- Stability/security of fuel supply (for supply-side resources)

- Site control

- Wheeling/interconnection considerations

Finally, 15 to 25 percent of the total available points should be awarded for non-economic factors such as fuel type, fuel diversity, unit size, project location, length of contract, conformance with terms of a standard agreement, energy efficiency/presence of a thermal heating load, FERC certification as a QF, monitoring and energy savings verification plans (for DSM resources), environmental impacts, and environmental benefits. A sample overall project
scoring system is presented in Figure 1.

BPA sirould build flexibility into their evaluation process by allowing negotiations on all but price issues with sponsors of projects contained in the initial award group. This would provide sponsors the opportunity to reconfigure their project or structure contractual terms in a manner that is consistent with northwest energy policy and resource needs.

\section{Environmental Considerations}

At a minimum, acquired projects must be designed, built, and operated to be in conformance with all applicable federal, state, and local permit and licensing requirements. Unavoidable or external environmental impacts still occur that; to some degree, could be mitigated through fuel or technology selection, plant siting, and incorporation of wastewater treatment or airborne emission reduction technologies into the project design. As mitigation entails additional capital and/or operating costs, resource sponsors tend to minimize their expenses by building only to existing regulatory requirements. This is not a proper course of action when the external environmental or societal costs are greater than the costs of mitigation.

We recommended that BPA assign a value to external environmental impacts of power plant development and design its environmental scoring approach so developers are rewarded (with additional points) when they take actions that reduce external environmental impacts. The project sponsor should continue to invest in environmental offsets until the increase in generating
cost outweighs the decrease in societal costs.

The New York Public Service Commission has determined that the societal cost of environmental externalities is valued at approximately 1.5 cents per $\mathrm{kWh}$ produced. With new generation costing $6 ₫ / \mathrm{kWh}$, an environmental weighting factor of approximately 20 percent $[1.5 /(1.5+6)]$ is deemed to be appropriate. BPA should complete a similar assessmert for the Parific Northwest so that an appropriate environmental weighting factor can be developed.

In their initial request for proposals, Orange and Rockland Utilities, in consultation with ti e New York St: te Energy Research and Development Authority, developed a comparative environmental rating form. With this environmental impact matrix, relative weights or importance values are assigned to such attributes as transmission line requirements, fuel de ivery, infrasiructure development, cooling water requirements and consumption, liquid waste jischarges, air quality ( $\mathrm{NO}_{\mathrm{X}}, \mathrm{SO}_{\mathrm{x}}$, particulate emissions, and carbon dioxide production), s olid waste production, environmental noise, land use, and visual/aesthe tic considerations. A project's environmental score is equal to the summation of the product of the attribute weights, times the impact scores, divided by the total available points for an environtnentally benign and unobtrusive project, times the environmental scoring factor. Orange and Rockland's Environmental Rating Form is shown in Figure 2. 


\section{Figure 1}

\section{Competitive Bidding Resource Acquisition Proposal \\ Scoring Factors and Maximum Values}

Price and Economic Confidence Factors:

- Price

Value, Points

- Front Loading

450

- Fuel Price Indexing

50

- Front Load Security

30

Total: Price and Economic Confidence Factors

Project Status and Economic Viability Factors:

- Project Technology/Technical and Economic Feasibility

- Project Management Team/Sponsors Experience

- Engineering/Design Status

- Permitting Plan, Schedule, and Milestones 15

- Financing Plan and Schedule

- Operating and Maintenance Plan

- Site Control

- Form of Liquidated Damages Fund

- Willingness to Post Increased Security

- Debt Cuverage/Return on Equity

25

- Marketing Plan (for DSM resources only) 40

- Stability/Security of Fuel Supply (for supply side only) 25

- Wheeling/Interconnection Cost Cunsiderations 15

(for supply side only)

Total: Project Status and Economic Viability Factors

Non-Economic Factors

Value, Points

- Fuel and Fuel Diversity (supply side only) 10

- Project Size (supply side only) 5

- Project Location (supply side only) 5

- Length of Contract 5

- Efficiency/Thermal Load 10

- FERC Certification as a QF (supply side only) 5

- Environmental Impacts 150

- Environmental Benefits 10

- Energy Savings Measurement and 25

Verification Plan (for DSM resources only)
Total: Non-Economic Factors

$\begin{array}{ll}\text { TOTAL: } & 1,000\end{array}$ 
FIGUAE 2

\begin{tabular}{|c|c|c|c|c|c|c|c|c|}
\hline $\begin{array}{l}\text { Environmont:? } \\
\text { Atributo }\end{array}$ & Welehs & 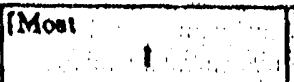 & 2 & lmpect $\quad 3$ & 4 & Lewal & tmpert & Score \\
\hline $\begin{array}{l}\text { Lransmitation } \\
\text { Line }\end{array}$ & 8 & Now Overhodstini & & $\begin{array}{l}\text { Now Overhend <ilin } \\
\text { Of New Underground } \\
>1 \text { Milo }\end{array}$ & $\begin{array}{l}\text { Now Underground } \\
\text { <1 Milo }\end{array}$ & $\begin{array}{l}\text { Urea Existing } \\
\text { Fucillity }\end{array}$ & & \\
\hline $\begin{array}{l}\text { Puel } \\
\text { Delivery }\end{array}$ & 2 & $\begin{array}{l}\text { New Railioend } \\
\text { Spur }\end{array}$ & Truck & $\begin{array}{l}\text { Berge or Now Ons } \\
\text { Ltwo }\end{array}$ & $\begin{array}{l}\text { Now Underground Om } \\
\text { Lino }\end{array}$ & $\begin{array}{l}\text { Existing Fuel } \\
\text { Facilition Or } \\
\text { Nono Required }\end{array}$ & & \\
\hline Cooling Waker & $\overline{2}$ & Once-Through Cooling & & Closed-Cycle Cooling & & None & & \\
\hline $\begin{array}{l}\text { Water Conaumption } \\
\text { rOAL NRKXW }\end{array}$ & $T$ & $20-225$ & & $<100$ & & $<10$ & & \\
\hline $\begin{array}{l}\text { Llauid Wask } \\
\text { Dhocharees }\end{array}$ & $T$ & $\begin{array}{l}\text { Direct Dlscharge } \\
\text { No Treatment }\end{array}$ & & $\begin{array}{l}\text { Waler Treatroem } \\
\text { Facility }\end{array}$ & & None & & \\
\hline $\begin{array}{l}\text { Sulfur Dioxide } \\
\text { Brinination } \\
\text { Filition BTU1 }\end{array}$ & 10 & 1.2 & & 0.4 & & 0 & & \\
\hline $\begin{array}{l}\text { Nitroden Oxides } \\
\text { Emission } \\
\text { rLbarmilion BTU! }\end{array}$ & 23 & 0.6 & & 0.3 & & 0 & & \\
\hline $\begin{array}{l}\text { Partetulass } \\
\text { Emission } \\
\text { RLba/Million BTU1 }\end{array}$ & 1 & 0.03 & & 0.01 & & 0 & & \\
\hline $\begin{array}{l}\text { Cirbon Dlaxtds } \\
\text { Erniasion } \\
\text { rLba/Militon BTU1 }\end{array}$ & 4 & 220 & & 150 & & 115 & & \\
\hline $\begin{array}{l}\text { Environmental } \\
\text { Noise }\end{array}$ & 3 & $\begin{array}{l}\text { Just Meets Property } \\
\text { Line Limit }\end{array}$ & & $\begin{array}{l}\text { Below Day-Timo } \\
\text { Ambient }\end{array}$ & & $\begin{array}{l}\text { Below Nighi-Tim } \\
\text { Ambient }\end{array}$ & & \\
\hline $\begin{array}{l}\text { Visival } \\
\text { Aesthelics }\end{array}$ & 2 & $\begin{array}{l}\text { Always Visible From } \\
\text { Senaltive Areas } \\
\text { [Parks \& Vislas] }\end{array}$ & $\begin{array}{l}\text { Generally Visiblo } \\
\text { From limportant } \\
\text { Recreation Areas }\end{array}$ & $\begin{array}{l}\text { Visible From Major } \\
\text { Highways or Train } \\
\text { Routes }\end{array}$ & $\begin{array}{l}\text { Seasionally } \\
\text { Visible }\end{array}$ & $\begin{array}{l}\text { Not Viaible } \\
\text { or Oterusive }\end{array}$ & & \\
\hline $\begin{array}{l}\text { Terrestriall\% } \\
\text { Of Site That } \\
\text { tncludes Wetlands } \\
\text { Mature Forest of } \\
\text { Prime or Unique } \\
\text { Area Thial Would } \\
\text { Ae Desrioved }\end{array}$ & $\begin{array}{c}2 \\
>=25 \%\end{array}$ & $<25 \%$ & $<15 \%$ & $<5 \%$ & None & & & \\
\hline Solid Wasto & 3 & $\begin{array}{l}\text { Off-Sito Dispotal } \\
\text { Of Ash }\end{array}$ & & $\begin{array}{l}\text { On-Site Dtsposal } \\
\text { Of Ash }\end{array}$ & & None Required & & \\
\hline
\end{tabular}

Environmental Rating $=($ Total Score $/ 300) \times 15$ 


\section{Security Requirements and Risk Minimization}

Risks for project sponsors can be reduced by establishing and adhering to bidding procedure timelines (for instance, 120 days for proposal preparation by the project sponsor, 60 days for iritial award group selection, 60 days for final selection, and 90 additional days for completing contract negotiations).

New Jersey's Board of Public Utilities requires each project sponsor to post a non-refundable $\$ 5,000$ bidder's fee. The purpose of this fee is to ensure that offers are made only by serious bidders.

New Jersey also requires the establishment of a liquidated damages fund that is tied to the developer's project milestones. It is recognized that risks are originally minimal and the actual damages or losses incurred by the utility increase as the project approaches its start-up date. Accordingly, payments are progressively made to the damages fund as the project passes key milestones with the total ccntribution equal to $\$ 18 / \mathrm{kW}$. Portions of the damage fund are forfeited to the utility if milestones are missed. The d.umage fund schedule is:

Payment Into Liquidated Damage Fund

Milestone Date

Bid Accepted

by Utility

Environmental Permit Application Filed

Environmental Permit

Received

Financial

Commitment Received

Commencement of

Active Construction

Total

\section{Coal Project}

$\$ 2 / \mathrm{kW}$

$\$ 2 / \mathrm{kW}$

$\$ 5 / \mathrm{kW}$

$\$ 2 / \mathrm{kW}$

$\$ 7 / \mathrm{kW}$

$\$ 18 / \mathrm{kW}$
All Other Projects $\$ 4 / \mathrm{kW}$

$\$ 2 / \mathrm{kW}$

$\$ 3 / \mathrm{kW}$

$\$ 2 / \mathrm{kW}$

$\$ 7 / \mathrm{kW}$

$\$ 18 / \mathrm{kW}$
Amount Forfeited To Utility If Milestone Is Missed

$\$ 1 / \mathrm{kW}$

$\$ 2 / \mathrm{kW}$

$\$ 1 / \mathrm{kW}$

$\$ 4 / \mathrm{kW}$

Boston Edison similarly requires a ccontract deposit of $\$ 15 / \mathrm{kW}$, with the project sponsor obtaining bonus points through a willingness to increase the deposit to $\$ 22.50 / \mathrm{kW}$. We recommerid that Bonneville establish a graduated security deposit'damage fund approach similar to the one developed in New Jersey.

New Jersey's BPU also recognizes that, due to reasons beyond a resource sponsor's control, a project's in-service date may have to be extended. Th ir Stipulated Agreement gives the developer flexibility by allowing the in-service date to be extended for up to 1 year by posting an additional payment of $\$ 6 / \mathrm{kW}$ into the liquidated damages fund. A project can be deferred for up to 3 years (with a total penalty payment of $\$ 18 / \mathrm{kW}$ ). After that, regardless of the reasons for project delay, the contract may be terminated or extended at the sole discretion of the power purchaser. We recommended that BPA include similar provisions in their competitive bidding approach. 
Power purchasers should eliminate the risks associated with signing a levelized or front-loaded contract, under which the cumulative payment to the sponsor might exceed the purchaser's cumulative avoided costs, by:

- Providing the purchaser with a lien on the project

- Providing a lien plus a cash equivalent security equal to an agreed upon percentage $(25 \%, 50 \%, 75 \%, 100 \%)$ of the cumulative overpayment

The sponsors should also be required to provide a cash equivalent security vehicle to secure their obligation to provide energy or capacity over the contractual period. In the event of a default and contract termination, the operating security $(\$ 5 / \mathrm{kW}$ to $\$ 50 / \mathrm{kW})$ should revert to the purchaser.

\section{Demand-Side Management Issues}

State energy office staff recommend that, to the maximum extent possible, a level playing field be established for the consideration of DSM and supply-side resources. Bidding can be used to augment or supplement existing BPA- or utility-sponsored conservation programs. The RFP should treat DSM opportunities equally. Beyond the pilot project stage, BPA's solicitation should request a single block of energy or capacity, without set-asides or quotas for elther conservation or supply options. A simultaneous solicitation procedure should be employed, with evaluation categories, weights, and scoring options the same, as much as possible, for demandand supply-side proposals. Similar opportunities and restrictions should apply, regarding minimum or maximum project sizes, contract lengths, and the availability of front-loading. Both supply - and demand-side proposals should be required to post a front-loading security deposit to protect against potential damages or loss of resources.

Geographical borders or restrictions should not be placed on providers of DSM resources. Owning and operating costs should be minimized through offering a single capacity or energy block, with no set-asides or quotas. Conservation transfers should be facilitated so no "franchises" or "reserved" territories are necessary. All customer classes should be equally treated and allowed in the bidding process with few restrictions or limitations on the conservation measures to be employed. The bidding process should be simple and the data requirements straightforward enough so that interested end-users can prepare offers and directly participate.

No caps should be established on the conservation savings offered for a bid at the individual provider level, project level, or at the RFP level.

Payments for DSM acquisitions should reflect both avoided capacity and energy costs. Customer contributions, in the form of cash payments, installation labor, and maintenance services should be included as part of the DSM measure cost. No losers, revenue erosion, unit cost, or rate impact tests should not be used to penalize cr discourage the selection of conservation opportunities. Acquisition should be based upon the principle of minimizing the net present value of system costs.

The bidding, scoring, and ranking system should be based upon an objective self-scoring procedure with "subjective" value judgments given objective self-scoring point values. The initial award group should be selected based upon the application of these objective scoring criteria with bidders encouraged to use self-scoring trade-offs to develop desirable bids that maximize ratepayer benefits. The procedure to evaluate bids must be both fair and open. 
Conservation acquisitions do differ from supply-side projects in the areas of meteririg and monitoring requirements. Evaluation, persistence, savings verification, "takebacks," changes in facility use or occupancy, and interactions botween improvement measures must be dealt with. Measured (metered) savings over the life of the measures should be given a strong preference over the use of savings estimates. BPA could allow approved engineering estimates to be used in lieu of monitoring to determine payments for energy savings. The predicted savings could be discounte $d$ by 2.0 to 30 percent to reflect current experience. Some utilities have allowed bonus scoring 1 oints to be awarded if monitoring of all or a sample of program participants is undertaken.

BPA should allow the use of statistically valid sample sizes and should develop appropriate evaluation methodologies or practices for different types of conservation resources. For instance, lighting retrofits may require only engineering estimates or spot measurements of before and after amperage draws; refrigeration improvements or high-efficiency motor change outs might entail before and after monitoring of loads over a shift or a limited period of time (i.e., one week or one month); while energy management systems, HVAC, or building envelope measures could require a comparison of annual weather corrected (for both heating and cooling degree days) baseline and after installation measurements. BPA should also allow measures in new construction that go beyond current practice or code requirements to be offered for acquisition through a competitive bidding program or secured at a rate based upon the highest price paid for a comparable resource under the prior bidding cycle. In essence, billing credits would be available at rates previously established through the bidding process.

BPA should also prepare tables showing both typical energy savings and/or demand reductions for a range of lighting retrofits (lower wattage relamping, use of specular reflectors, electronic ballasts), appliance efficiency or energy efficient HVAC measure adoptions, chiller and highefficiency motor change outs, and refrigeration improvements. Savings estimates could then quickly be made by multiplying the number of measures installed in each technological category times the estimated savings per measure. This approach was taken by the Long Island Lighting Company (LILCO) in an RFP that targeted specific conservation measures. LILCO also offers up-front payments, similar to rebates, for the measures selected.

\section{Contract Formation}

BPA should minimize negotiation transaction costs and time requirements by developing a standard or generic contract. Timelines and deadlines should be established for the negotiating and signing of these contracts. Contracts with variable lengths should be developed and readily offered.

BPA must develop an expedient process to clarify and verify project sponsor representations. Along these lines, a Notice of Intent to bid might be required, with the submittal of appropriate sponsor information and documentation. 


